\title{
Garliavos provizoriaus Kazio Aglinsko ir Jono Basanavičiaus bičiulystė
}

\author{
INGA STEPUKONIENÉ \\ Vytauto Didžiojo universitetas, Lietuvių literatūros katedra, K. Donelaičio g. 52-212, LT-44248 Kaunas \\ El. paštas: i.stepukoniene@hmf.vdu.lt
}

\begin{abstract}
Straipsnyje apžvelgiamas vieno iš Maskvos lietuvių studentų būrelių XIX a. steigèjo, vieno iš leidinio Aušra sumanytojų, slaptos lietuviškos spaudos platintojo ir knygnešio Jono Basanavičiaus draugo ir bendražygio Kazio Aglinsko gyvenimas ir visuomeninè veikla, aptariama lig šiol nepublikuota gausi jo korespondencija Jonui Basanavičiui. Darbo metodai: analitinis interpretacinis, aprašomasis, fenomenologinis.
\end{abstract}

Raktažodžiai: aušrininkai, slapta lietuviška spauda, visuomeninè veikla

\section{IVADAS}

Kazys Aglinskas - viena garsiausių XIX a. antrosios pusès - XX a. pradžios Garliavos, o kartu ir Lietuvos asmenybių. Tai buvo didžiulis savo krašto, gimtosios žemės ir tautos, jos kalbos mylėtojas, tèvynės patriotas, visas savo jẻgas ir gyvenimą paskyręs tautinès dvasios budinimui, lietuvių tautos gerovès kèlimui. Lietuvių studentų būrelių Maskvoje steigèjas, telkęs tautiečius lietuvybès darbui, vienas iš lietuviškos pogrindinès spaudos, ypač Aušros, platintojų, J. Basanavičiaus bičiulis ir draugas. Iš Maskvos sugrịžęs ị Lietuvą $1885 \mathrm{~m}$. Aglinskas Garliavoje ịsteigia vaistinę ir joje platina draudžiamus lietuviškus spaudos leidinius, globoja knygnešius. Jo namai tampa vienu didžiausių slaptų knygų persiuntimo punktų Suvalkijoje. Deja, nei istorijos, nei literatūros moksle jo reikšmè lietuvių kultūros istorijai dar nèra pakankamai apibrèžta, lig šiol nėra pavykę išsiaiškinti daugelio jo biografijos faktų, deramai neatskleisti jo ryšiai su Jonu Basanavičiumi. Kazio Aglinsko asmenybè ir veikla glaustai aptarta Leono Būdvyčio straipsnyje „Karštai mylintis tèvynę“ KMU leistame leidinyje Ave vita (1992), taip pat negausių biografinių žinių esama Kauno rajono bibliotekos Bibliografijos skyriuje (muziejininkè Tamoševičienè).

Šio straipsnio tikslas - apžvelgti Kazio Aglinsko biografijos momentus, papildant ją iš pateikèjų ir lig šiol dar neištirtų literatūros šaltinių sukaupta informacija, taip pat išanalizuoti LLTI fonduose saugomus Kazio Aglinsko laiškus Jonui Basanavičiui, rašytus nuo 1887 iki 1924 metų, padedančius atskleisti juos siejusius ryšius, aptarti laiškuose svarstomus asmeninius ir visuomeninius klausimus.

Siekiant tai atskleisti, straipsnyje derinami įvairūs metodai - aprašomasis, analitinis interpretacinis, fenomenologinis. 


\section{KAZYS AGLINSKAS: BIOGRAFIJOS METMENYS}

Kazys Aglinskas gimė $1851 \mathrm{~m}$. netoli Garliavos įsikūrusiame Girininkų kaime, tuomet Pakuonio valsčiuje. Tẻvai leido sūnų mokytis, nes tikẻjosi, kad iš jo išeis geras kunigas. Tačiau veržlus jaunuolis nejaute tam pašaukimo ir atsisake stoti ị kunigų seminariją, sukeldamas didžiulį konfliktą šeimoje, po kurio tèvas atsisakè remti sūnų materialiai. Vis dèlto šis nepalūžo ir tvirtai laikèsi savo nusistatymo. Baigęs penkias Marijampolès gimnazijos klases kaip vienas geriausių mokinių ir priverstas mesti mokyklą, išvažiavo ị Maskvą. Čia jam pavyko įsidarbinti tuo metu garsioje „Fereino“ vaistinèje, kurioje išdirbo trejus metus. Tuomet išlaikęs egzaminus ir igijęs provizoriaus padėjejjo pareigybę išvyko dirbti ị Petrapilị. Po poros metų vèl grịžo ị Maskvą ir ịstojo ị Universiteto Farmacijos skyrių.

Besimokydamas Maskvoje K. Aglinskas susipažista su Jonu Basanavičiumi, ir ši tvirta, didžiule draugyste išlieka iki pačios jų gyvenimo pabaigos. Tuo metu Maskvoje studijuojantys lietuviai ima burtis į pirmajji lietuvių studentų būrelị, ir Kazys Aglinskas aktyviai dalyvauja, telkdamas ir organizuodamas tautiečius. Maskvoje tuo laiku mokosi filologai Andrius Botyrius, Jurgis Miklaševičius, Petras Markūza, Vincas Staniškis, matematikai Blaškevičius (1), Vincas Pietaris, Vincas Pašukanis, medikai Vincas Gilius, Stanislovas Čirvinskis, Matas Puišys, Jonas Kudirka, Andriukaitis, Mykolas Oleka, Kriščiūnas, Stasys Matulaitis, Krakauskas, Antanas Buivydas, Adomas Sketeris, vaistininkystę studijuoja M. Kasakaitis, Jonas Račiūnas, Vincas Linka, Jonas Petrauskas, Vincas Mičiulis, Bujenauskas. Susirinkę jie svarsto lietuvių nacionalinès padèties, tautinès tapatybès, savimonės žadinimo klausimus, kalba aktualiomis spaudos temomis. Būtent šiame būrelyje gimsta idèja steigti lietuvišką laikrašț Aušra. Pasak L. Būdvydžio, šie jaunuoliai buvo „pirmieji naujos atgimstančios Lietuvos spinduliai“" [2].

Baigęs universitetą ir igijęs farmacininko specialybę K. Aglinskas sugrịžta ị Lietuvą. $1885 \mathrm{~m}$. apsigyvena Garliavoje - čia ịsigytame name ịsteigia miestelio vaistinę (2). Jis ne tik pardavinejja vaistus, bet ir gydo ligonius, dirba kaip gydytojas - tą lemia nemenkos jo medicinos žinios, įgytos skaitant medicininę literatūrą, plačiai domintis viskuo, kas susiję su ligomis ir jų gydymo būdais. „Žmonių atmintyje jis atmenamas kaip malonus, mandagus, nuoširdus specialistas, inteligentas. Buvo aukšto ūgio, liesas, žilais plaukais, lazdele pasiramsčiuodamas vaikščiojo lètai“ [4]. Pasak K. Čebelio (1899-1990), gimusio ir augusio Garliavoje, „nebuvo lupikas. Duodavo biedniems žmonėms vaistų už dyka“ [8, 6]; garliavietė Izabelè KalinaitėStasiulevičienè (1911-1990) prisimena, jog ją „,dažnai tèvas siųsdavo parnešti iš Aglinsko vaistinès vaistų. Mamai skaudėdavo po krūtine. Nuo Aglinsko vaistų jai palengvédavo. Tai buvo malonus, mandagus, nuoširdus žmogus. <> Pasivaikščioti eidavo kasdien“ $[8,6]$.

Garliavos vaistinè tampa ne tik pagalbos vieta susirgusiems, bet ir lietuvybès žadinimo židiniu. K. Aglinskas, dar nuo studijų laikų turẻdamas daug ryšių su tautiškai susipratusiais lietuviais, visokeriopai remia ir globoja knygnešius, name slepia uždraustą lietuvišką spaudą, organizuoja platų laikraščiu ir knygų platinimo tinklą. Jo namai tampa „stambiu lietuviškų knygų persiuntimo (iš kairiosios Nemuno pusès) punktu" [2].

Šiame darbe jam itin daug talkino žmona Ona Aglinskienè. Ji ne tik priiminėdavo atgabentas laikraščių ir knygų siuntas, jas slëpdavo, bet ir organizuodavo leidinių išgabenimą tolimesniais keliais, šelpė ir maitino užejjusius knygnešius. Namus ne kartą krètė caro žandarai, ieškantys draudžiamos spaudos. Vienas toks kartas buvo lemtingas. Kaip prisimena knygnešystės Lietuvoje istorikas P. Ruseckas, vienos kratos metu, kai K. Aglinsko nebuvo

(1) Kai kurių tuo laiku Maskvoje studijavusių lietuvių vardų nepavyko identifikuoti.

(2) Šis namas, paženklintas 22 numeriu (Vytauto g.), tebestovi iki šiol. 
namuose, žandarai „taip smarkiai p. Aglinskienę išgąsdino, taip ją suerzino, kad ji po to sunkiai susirgo ir ... nelaiku pasimirè. Tai bus tikra knygnešystės auka “ [5]. Ona Aglinskienė mire praejjus keletui dienų po kratos - nuo baisių sumušimų ir nervinio sukrètimo, tačiau net ir smarkiai daužoma, spardoma lietuviškų laikraščių slaptavietės neišdavė (3). Ji mirẻ visai jauna, su vyru taip ir nespejjusi susilaukti vaikų. K. Aglinskas, likęs našliu, gyvenime daugiau nevedè, kaip ir jo artimiausias draugas daktaras Jonas Basanavičius, mirus jo žmonai Elei.

Po minètų dramatiškų ịvykių K. Aglinskas ir toliau buvo persekiojamas, todèl jis „knygų, skiriamų platinti, nebepriimdavęs, bet surasdavęs vietų, kuriose ne tik knygos, bet ir knygnešiai galèdavo be pavojaus prisiglausti" [5]. K. Aglinsko, kaip vieno iš Aušros steigèjų, draudžiamos literatūros platintojo ir karšto tèvynès mylètojo, pavardè buvo plačiai žinoma tuometinei Lietuvos visuomenei. Jo namuose, net ir rizikuodami, nuolat lankydavosi krašto visuomenininkai, kuriuos jis visuomet maloniai priimdavo ir kuo galedamas remdavo. P. Ruseckas prisimena, jog jam „,visai netikètai spaudos leidimo metu (1904-1905 m.) pro Garliavą vykstant, Aglinsko visai nežinant ir nepažịstant, tik jo parašą prie durų pamačius, teko pas ji užeiti. Jis tuoj, iš pirmojo pamatymo, kaip savo artimiausią draugą priemė, vaišino ir keletą dienų neišleido, kol iš nuovargio atsigavau, atsilsèjau. Tikrai šaunus ir svetingas buvo žmogus ir savo gerumu nesivarže“ " [5].

Knygnešio Petro Varkalos dukra Antanina prisimena, jog 1903 m. P. Varkala buvo suimtas ir įkalintas Kauno kalejime, tačiau K. Aglinsko pastangomis išlaisvintas. Per Pirmąji pasaulinị karą Varkalų šeima buvo pasitraukusi ị Rusiją. 1918 m. grịžę su keturiais vaikais rado degančius namus. Šioje bẻdoje vèl padejo K. Aglinskas, nors pats gyveno labai kukliai ir jo namas buvo po gaisro [6].

Profesorius Petras Šalčius savo prisiminimuose rašo, jog jam, dar Marijampolès gimnazijos mokiniui, prieš Pirmąji pasaulinị karą besilankant pas K. Aglinską teko susipažinti su čia viešèjusiu Jonu Basanavičiumi, ir ši pažintis itin sustipinusi gimnazisto norą darbuotis gimtojo krašto labui [9].

K. Aglinskas bendravo su iškiliausiais to meto lietuviais inteligentais: Tomu Ferdinandu Žilinsku, Jonu ir Petru Vileišiais, Petru Kriaučiūnu, Kaziu Griniumi, Stasiu Matulaičiu, M. Davainiu-Silvestravičiumi, Jurgiu Miklaševičiumi, Jonu Šliūpu, Juozu Gabriu-Paršaičiu bei jo šeima, pas jị lankydavosi garsiausi Sūduvos knygnešiai: jų karaliumi vadinamas Juozas Kancleris, Antanas Baltrušaitis-Antanèlis ir kiti. Vienas ištikimiausių viso jo gyvenimo draugų buvo daktaras, lietuvių tautos patriarchas Jonas Basanavičius. Po Didžiojo Vilniaus Seimo (Lietuvių suvažiavimo Vilniuje) 190512 04-5 d. J. Basanavičius ištisas savaites buvo priverstas slapstytis nuo žandarų. K. Aglinsko namai jam ir tapo priglaudžiančia ir slepiančia pastoge. I Garliavą pas K. Aglinską J. Basanavičius atvykdavo itin dažnai - dalytis svarbiomis lietuviškos visuomeninès veiklos žiniomis, pailsèti po sunkaus darbo, rašyti ramioje aplinkoje, gydyti žmonių.

Garliavoje pas K. Aglinską buvodavo garsus Marijampolès mokytojas Petras Kriaučiūnas, kuris, pasak J. Basanavičiaus, „ne vienam jaunadvasiui įkvẻpe karštą meilę ị savo pavargusią tautą ir josios kalbą. Daugiausia jo dèka lietuvystė atgaivinta Suvalkų gubernijoje" [1]. K. Aglinskas daug bendravo ir su kitu Maskvos universiteto bičiuliu - daktaru Stasiu Matulaičiu, kilusiu iš Stebuliškių kaimo. Grižęs ị Lietuvą darbuotis, S. Matulaitis nuolat platino lietuviškas knygas, kaip ir jo broliai Liudvikas ir Juozas Matulaičiai - Varpa, Ūkininką, Tẻvynès sarga, Amerikoje leidžiamą Vienybę lietuvininkų ir daug kitų tuo metu

(3) Marijos Litvaitienès pasakojimas vaikaičiui Petrui Nėniui. Autorès pokalbis su P. Nėniumi 19950712. 
draudžiamų leidinių, kurie, pasak P. Rusecko, „iš apsnūdusio jaunuolio padarydavo karštą lietuvị patriotą" $[5,170]$.

Daugelis minètų lietuvių patriotų buvo susibūrę $\mathfrak{i}$ "Sietyno“ draugiją, kurią sunaikinti buvo didžiausias caro žandarų viršininko Vonsiackio rūpestis. Tai iš esmès jam pavyko itin suaktyvinus knygnešių persekiojimą 1897-1899 metais. Šiuo laiku Suvalkijoje buvo suimti ir nuteisti, daugiausia tremtimi, 34 žmonès (Jonas Kriaučiūnas, kunigas Bulvičius, Oleka, Petras Matulaitis, Pranas Matulaitis, Juozas Kačergius, Juozas Armastauskas ir kt.). 1899 m. rugsėjo 3 d. atliekama krata pas mokytoją Juozą Jasaitị, kilusį iš Stanaičiu kaimo ir čia gyvenusị, K. Aglinsko bendramintị. Po keleto savaičių krečiami ir K. Aglinsko namai, bet tuo metu, neradus nelegalios spaudos ir neturint objektyvių irodymų, bylos jam sukurpti nepavyko.

Garliavoje K. Aglinskas subūrẻ literatūros mylètojų kuopelę, kuriai priklausė J. Andziulaitis-Kalnėnas, J. Mačys-Kèkštas, K. Sakalauskas-Vanagèlis ir kiti. Šioje kuopelèje buvo dalijamasi Vakarų Europos ir lietuvių literatūros naujienomis, svarstomi aktualūs lietuvių spaudos, knygų leidybos, švietimo ir kiti visuomenès gyvenimo klausimai.

1905-ieji buvo neramūs visoje Lietuvoje. Istoriniai ịvykiai sukèlė didžiulį chaosą. Kaip teigia K. Grinius, $1905 \mathrm{~m}$. Sūduvoje žmonès pradèję aktyviai priešintis caro valdžiai: „visose lietuviškose apskrityse jaunimas arba nuginklavo policininkus, arba privertė juos pabėgti iš kaimų $i$ apskrities miestus. <> Degtinès monopolio krautuvės provincijoje buvo arba išdaužytos, arba užsidarè. Pradžios mokyklos buvo apvalytos nuo carų portretų ir uždarytos. Nekenčiamus miškų tarnautojus šaudè. Socialdemokratų partija (L. S. D. P.) „eksproprijuodavo valstybinių ir pusiau valstybinių ịstaigų kasas ir tuo papildydavo savo iždą“. Rusijos vidaus reikalų ministerio Makarovo pranešimas Dūmos atstovams rodo, kad Šakių apskrityje revoliucinis sąjūdis 1905 m. rudenį buvo pasiekęs rekordą visoje Rusijoje [3, 129-130].

K. Griniaus teigimu, socialdemokratų partijos „reikalams nepritekdavo pinigų. Dèl to jie iškraustydavo valstybinių degtinès parduotuvių, tuomet monopoliu vadinamo, kasas, pačius monopolius išdaužydavo, degtinę upeliais paleisdavo... Partijos reikalams eksproprijuodavo ir girininkų kasas ... taip pat sustabdydavo pašto vežimus ir atimdavo pinigus" $[3,94]$.

I tokias nemalonias istorijos girnas tuo laiku patenka ir K. Aglinskas, spejjama, kad neatsitiktinai. Kaip prisimena K. Girnius, Sūduvoje tuo laiku atsiranda ir „nedora plěšikų kuopa, revoliucijos padugnès, revoliucionieriai išsiveržèliai“, „giltiniečiai“, pasivadinę „Lietuvių Komunistų Giltinès Kuopa“ ir plèšę nekaltus žmones. Jie „apiplěšè Garliavos dekaną kun. Budzeiką, Skriaudžių kleboną kun. Bliūdzinską, Gudelių (Ivoniškių) dvarininką žydą Blankšteiną, užmušdami iš Varšuvos atvažiavusị svečią; Garliavos vaistininką provizorių Kazị Aglinską ir dar vieną kitą (apiplèšè - aut. past. )“ [3, 91-92].

1907 m. K. Aglinskas tapo Lietuvos mokslo draugijos nariu. Iૃstodamas jis įnešè 200 rublių ir draugijos buvo pakeltas ị narius labdarius.

Prasidejus Pirmajam pasauliniam karui K. Aglinskas pasitraukè i Rusiją - apsistojo Voroneže, vèliau persikèlè ị Gluškovą (Kursko gub.). 1918 m., sužinojęs, kad kuriasi Nepriklausoma Lietuva, grịžo i̇ Lietuvą. Kaip prisimena Kazys Čebelis, jis grịžo labai neturtingas, vienišas, bet J. Basanavičiaus padedamas atkūrè vaistinę [9]. Mirè sunkiai susirgęs 1924 m. rugpjūčio 23 d., sulaukęs 73 metų. Mirties aplinkybes prisimena garliavietė Michalina Poderytė-Gervienė, gimusi 1909 m.: „Garliavoje tarnavau pas K. Aglinską, vaistininką. Pilsčiau miltelius ir kitus darbus dirbau vaistinejje. 
Vaistininkas ilgai sirgo, nors dirbo iki pat mirties. Rytą nuejjusi, radau ji mirusị. Suejję žmonès aprengė, padarẻ karstą iš nedažytų lentų (tokia jo buvo valia), įdejjo karstą ị vežimą, o vežime buvo prikrauta šiaudų. Ir išvežè - neprisimenu kur, Prienų ar Marijampolès lik. Palydejome su mama ligi Garliavos galo ir sugrįžome namo. Ta viena padvada [vežimas] jị ir išvežè (lyg ỉ Veiveriukus - ar netoli Prienų, ar Skriaudžių)“ [9]. Kapas, deja, nerastas. Prieš mirtị norejjo visą savo turtą palikti Lietuvos universitetui, bet nespéjo užrašyti.

Garliavoje jo vardu pavadinta gatvè (1990). Prie namo Vytauto g. 22, kuriame jis gyveno, 19961018 atidengta memorialinè lenta. Knygnešio, visuomenès švietejo, vieno iš Aušros laikraščio steigejjo provizoriaus Kazio Aglinsko pavardè ịrašyta stogastulpyje, pastatytame 19971029 prie Garliavos bibliotekos (Vytauto g. 21) knygnešių atminimui.

\section{KAZIO AGLINSKO KORESPONDENCIJA JONUI BASANAVIČIUI: MASKVOS MOKSLO LAIKAI SURIŠO MANO DVASIĄ SU TAVĄJA IKI GRABO}

K. Aglinsko asmenybę plačiai atskleidžia išlikusi gana gausi jo korespondencija Jonui Basanavičiui. Jų susirašinèjimas prasidèjo dar abiem studijuojant Maskvoje ir tęsėsi iki pat gyvenimo pabaigos. LLTI fonde saugomi išlikę $92 \mathrm{~K}$. Aglinsko laiškai J. Basanavičiui, tačiau jų neabejotinai buvo kur kas daugiau - susirašinèta gana intensyviai tiek asmeniniais, tiek visuomeniniais klausimais [8].

\section{Maskvos studentų brolystė}

Pirmasis išlikęs K. Aglinsko laiškas J. Basanavičiui, rašytas 1879 m., vaizdžiai liudija tipišką XIX a. pabaigos lietuvių studento, besimokančio svetimame krašte, būklę: Mano brolis Mykolas parašè, kad prižadejai prieš išvažiavima i Gudija būti Garliavoj ir iš čia nuvažiuoti j Girininkus pas mano senukus tèvus, - jei nepatingési, tai neužmiršk pažiürèt, ar neturi jie gero, plono, pilko, šukuoto milo - paimtum kelis mastus man ant žiemos pasisiūdint ka nors. <>

Daugiau viskas Tau yra žinoma, sèdžiu toje pačioje vietoje, gyvenu vienas, niekur nebū$n u$, nes pinigu visai neturiu, nuomininku dar negaunu, ir už universiteta penktadienį turèsiu sumokèt, jei tik išeis, ir taip smilkstu kaip žolès nedegas diena po dienos - vis tolyn, vis senyn, o smertis - vis artyn. <>

Laukdamas Tavo atvažiavimo bučiuoju po šimtą kartų.

Mylintis Tave Kazimieras (1879 08 29).

1884-ųjų vasaros pabaigoje rašytame laiške K. Aglinskas bičiuliui praneša, kad gavo leidimą ịsteigti Garliavoje vaistinę ir labai nori ten vykti, bet dvejoja, ar tai prasminga daryti prieš rudenị ir žiemą, žinant, koks atšiaurus tuo metų laiku ten klimatas. Vis dèlto po kurio laiko išvyksta - K. Aglinsko vaistine Garliavoje pradeda veikti nuo $1885 \mathrm{~m}$. ir iškart tampa susipratusių lietuvių būrimosi vieta, veiklos centru. $1887 \mathrm{~m}$. rašytame laiške bičiuliui, mąstančiam apie gyvenamąją vietą, K. Aglinskas išsako savo ir Maskvos studiju laikų draugo Jurgio Miklaševičiaus ideją J. Basanavičiui visam laikui apsistoti Garliavoje, jo namuose: Pajautos mano, mielas Jonai, Tavo atžvilgiu ne kiek nepasikeitė ir pasiryžęs viska padaryti, ka tik galiu. Man rodos, kad ir be šito prašymo Tu turètum sustoti pas mane, jei tik būtum Lietuvoj, o tada plačiau pasišnekètume apie viską, kaip ir apie tai, ar verta būtu Tau apsigyventi Garliavoje, ar ne. Aš viską, rodos, prigalèčiau, kad Tu pasiliktum pas mane. Dèl to, mielas Jonai, jeigu ketini parkeliauti namo - Lietuvon, tai būk toks geras, parašyk man nors trumpai, kada parkeliausi ir kokiomis salygomis apsigyventum Garliavoj (1887 09 06). Tuokart J. Basanavičius Garliavoje dèl ịvairių priežasčių, visų pirma politinių, neapsistojo, 
bet šis klausimas tarp dviejų bičiulių gyvenime svarstytas dar ne kartą - J. Basanavičius ketino ịsigyti Garliavoje nuosavybę.

K. Aglinsko laiškai J. Basanavičiui atspindi didžiulę ir nuoširdžią šių iškilių asmenybių draugystę. K. Aglinskas nuolat kviesdavo bičiuli atvykti paviešèti ị savo namus, pasitikdavo stotyse su savo vežimu - tą liudija gausybẻ jam siųstų atvirlaiškių iš Garliavos (Godlevo) pašto, kuriuose trumpai teiraujamasi apie atvykimo datą ir net valandą, pranešama, kada galès laukti, pvz.: Apie 5 valanda pasistengsime büti Kauno stotyje su savo vežimu, kad pasitiktume mūsų laukiama sveteli. Laukdamas siunčiu labas dienas. Tavo Kazys [8] (1905 08 06). Remdamasis sena studijų laikų pažintimi ir giliu dvasiniu bendrumu bei brolišku artumu, K. Aglinskas kviesdavo J. Basanavičių jo namuose sutikti pačias gražiausias pavasario šventes - šv. Velykas. 1910 m. kovo 20 d. laiške jis rašo: ,Br. [angus] J.[onai], tvirtai tikedamas, kad operacija Tavo nusiseke, turiu vilties matyti Tave pas save Garliavoje sveika ir linksma Velyku švenčiu, todèl ir neapsunkinu savo smulkiom žiniom, nes nieko svarbaus per ta laika pas mane ir neatsitiko - vien tik labai Tavęs išsiilgau ir parvažiuojanti Velykų labai laukiu. Tavo Kazys. Itvertinant laiškų-kvietimų gausą, akivaizdu, kad jo labai laukdavo visuomet, kaip paties mieliausio bičiulio ir svečio. Mielas J.[onai], Brangus brolau, Godotinas Tamista - tokiais kreipiniais nuolat prasideda laiškai, kuriuose matyti rūpinimasis kitu, išpasakojami svarbiausi reikalai ir rūpesčiai, dalijamasi džiaugsmu ir nerimu. Maskvos mokslo laikai surišo mano dvasią su Tavaja iki grabo, - rašè K. Aglinskas J. Basanavičiui 1907 metais.

\section{Garliavos apylinkèse}

Atvirukai su trumpomis žinutemis ir pranešimais iš Garliavos nuolat skriedavo ị Vilniaus viešbučius, ị Prahą, Austriją, Bulgariją - sekdavo J. Basanavičių visais tolimais jo keliais. Daugelis jų - lakoniško informacinio pobūdžio: prašymas pranešti apie parvykimą, fragmentiški brūkštelèjimai apie sveikatos būklę, miestelio buitinius ir visuomeninius ịvykius, trumpos naujienos iš bendrų pažistamų gyvenimo. Itin gausūs - apie orą, už lango regimą gamtą kviečiant pailsèti po sunkių darbų ir atsigauti pavasarejjančioje apylinkių miškų, pievų ir laukų gaivoje. Iš šių atvirlaiškių matyti, jog abu buvo didžiuliai gamtos mylètojai, kurie, vos saulei pakilus aukščiau, mėgdavo paklaidžioti po miesteli supančias girias, pasigèrèti Sūduvos laukų horizontu, stebẻdavo visą gamtos atbudimą - nuo besiskleidžiančios gèlès iki sučiulbusio paukščio. Pas mus truputi šilčiau, gruodo nèr, diduma lauku jau žaliuoja, gegutè kukuoja, visi paukšteliai čiulba, ypač juodykis ir vieversys. Turédamas laiko daugiau parašysiu, tuom tarpu siunčiu tau daug labu dienų, ir tariu: mano namas - tavo namas (jeigu Tu nori). Tavo Kazys (1909 05 04). Ši ištarmè - bene ryškiausias jų didžios dvasinès bendrystès ir stipraus tarpusavio ryšio paliudijimas. Kiekvienas J. Basanavičiaus atvykimas ị Garliavą K. Aglinsko laiškuose įvardijamas kaip "grịžimas“ namo, parvykimas ị "tikrąąa“" gyvenamąją vietą (1909 0417 d. laiškas). Kad Garliava J. Basanavičiui išties buvo tapusi miela buvimo erdve, liudija tai, jog būdamas Lietuvoje Garliavoje pas K. Aglinską jis buvodavo kur kas dažniau nei savo gimtinèje Ožkabaliuose.

K. Aglinskas pats dažnai su reikalais vykdavo ị Vilnių ir šiame mieste aplankydavo J. Basanavičių. Nuo kelionių jị sulaikydavo tik bjaurus oras, grasinantis sukelti kosulį, ir prasidejjusios ịvairios epidemijos, nuo to jis stengdavosi atkalbèti ir savo draugą. Tokios laiškų eilutès išties dvelkia nuoširdžiu rūpinimusi savo artimu, jo sveikata. Garliava savo ruožtu suvokiama kaip „gryno oro“, dvasinès atgaivos teritorija, ỉ kurią verta skubèti iš 
Vilniaus: Br. J., turiu tvirta vilti, kad praejus Mokslo Draugijos susirinkimui, pamesi Vilniu su jo užterštu oru, o pasinaudodamas tyru rudens oru, aplankysi Garliavą. Rakta ir kai kuriuos paveikslèlius išsiunčiau - turi būti gerai (1908 08 14).

Atvykus J. Basanavičiui, abu aktyviai bendraudavo su apylinkès žmonėmis, dažnai viešèdavo Zagrados dvare pas Gustaičius, žvalgydavosi aplinkinėse vietovėse rinkdami tautosa$\mathrm{ką}$, lanke istorines ir legendomis apipintas įžymesnes vietas. Jiems labai rūpèjo visa, kas tik bent kiek ryškiau siejosi su lietuvių tautos praeitimi, jos etnografija, papročiais ir mitologija. Garliavoje ir apylinkèse K. Aglinskas rinko senovinius daiktus, kuriuos vèliau atiduodavo J. Basanavičiui, itin besirūpinusiam sukaupti kuo turtingesnę Lietuvos dvasinio ir kultūrinio paveldo kolekciją, kuri tapo ypač svarbi steigiant Lietuvių mokslo draugiją. $1908 \mathrm{~m}$. kviečia draugą aplankyti seną Jiesios malūną, kurio liekanos dar išlikę ir apie kurị išgirdęs iš Dūmos atstovo Griniaus; kitame laiške - senąjt šventą ir padavimais apipintą uosị, augusị tarp Padainupio ir Digrių kaimų. Senobinį barsuka turiu, - praneša K. Aglinskas svarbią naujieną savo draugui atvirlaiškyje 1909 m. lapkričio 2 dieną. Viename laiške daktarą moko, kaip klijais suklijuoti suskilusias senovines vazas. 19090710 dienos laiškutyje praneša, jog sužinojęs, kad Zagrados laukuose yra senas kapinynas, apie 150 metu, kuriame jau nustota laidoti. Dar paaiškina, jog čia laidota kelis šimtus metų ir kad bus galima naudotis, manau, Gustaitis kliūčiu nedarys. Franckevičiene parodys ta vieta - šiandien ariama sèjama dirvą. Prižada artimiausiu metu apsilankyti pas dvaro savininką Kazimierą Gustaitị ir pasikalbėti tuo klausimu. Iš J. Basanavičiaus užrašų žinoma, kad ši kapinyną jie išties kasinejo; J. Basanavičius aprašè čia užfiksuotus duomenis apie vargingus Suvalkijos baudžiauninkų palaidojimus be jokių ikkapių [1]. Tuo pat metu Garliavoje ir jos apylinkèse iš vietinių gyventojų J. Basanavičius užrašinejjo istorinius duomenis apie Garliavą ịkūrusį ir čia bažnyčią pastačiusi grafą Jozefą Godlevskị, Napoleono kariuomenès žygị per Garliavą. Čia jis rinko ir pasakas, dainas - jų Zagrados dvare jam padainavo šeimininkẻ Ieva Gustaitienè su dukra Kazimiera.

\section{Spaudos atgavimo tarpsnis}

K. Aglinskas gyveno tais pačiais tautiniais rūpesčiais, kaip ir J. Basanavičius. Jis aktyviai sekè visus Lietuvos ir pasaulio politinius bei visuomeninius įvykius, kiekvieną ryškesni lietuvybès proveržio krustelejjimą vertino labai palankiai ir tuo džiaugèsi, rèmè, kiek išgalèjo. Didžiausią džiaugsmą jam sukelia žinia, kad caras Nikolajus II leido lietuviams spaudą lotyniškais rašmenimis; atvirlaiškyje klausia J. Basanavičiaus: ar neketini <> grǐžti Lietuvon, nes čia galima dabar atnešt naudingiausia pagalba Lietuviškai dvasiai (1904 05 26), net keliuose laiškuose dèkoja už jo didelius darbus gimtajam kraštui ir ragina kuo greičiau parvykt iš Bulgarijos, nes dabar atsiradusi nauja galimybė duot impulsa Lietuvai (1904 08 20). Perskaitęs Viltyje apie policijos priežiūros J. Basanavičiui nutraukimą, iškart siunčia jam emocingą pasveikinimą ir kviečia atvykti į Garliavą pasidžiaugti pasiektu didžiu laimèjimu (1904).

1904 m. dažnejja K. Aglinsko išvykos i Vilnių - aktyviai bendrauja su Petru ir Jonu Vileišiais, kunigu Ambrozevičiumi, Miklaševičiumi; rūpinasi lietuvišku draugijų kūrimu. Nuolat J. Basanavičiui primena, kad Petrapilio ir Vilniaus lietuviams svarbu savo draugijose: 1) sustatyti programa Lietuvystès ir paskelbti rusų bei lenkų laikraščiuose, 2) būtinai reikalinga aukcionieriška lietuviška draugystè - pinigai lietuviškai spaudai. Jam pikta, kad daugelis tautiečių atsisako aukoti, kol tos spaudos nèra, kad žada tai daryti, kai tie lietuviški laikraščiai jau bus leidžiami. Piktinasi, kad kunigai duoda pinigų tik klerikalų leidiniui ir 
mano, jog Lietuvai to užteks. Todèl jis prašo J. Basanavičių viešai kalbėti, išsakyti savo nuomonę šiais klausimais, nes daugiau tokia situacija tęstis nebegali.

Petro Vileišio namuose susibūrę lietuviai inteligentai svarsto idèją steigti Lietuvių mokslo draugiją. K. Aglinskas džiaugiasi, kad jos programa parengta pagal jo „dvasią“, žada aktyviai prisidèti prie šios veiklos. Ją ịsteigus, tampa tikruoju nariu ir, be įneštų 200 rublių, dovanoja dar 34 tomus savo privačios namuose sukauptos bibliotekos knygų.

Tuo pat metu aktyviai bendrauja su Kauno lietuviais, telkia ir žadina juos lietuviškai veiklai. I ji, kaip pripažintą lietuvybės tarną, kreipiasi tie miestiečiai, kuriems svarbu Kaune pradèti leisti lietuviškas knygas. Aš tikrai noréčiau pradèti Kaune naudingu lietuvišku knygeliu leidyklą, bet negaledamas padaryt to darbo savo jëgomis, ieškau vienodai mąstančiu ne tik dèl pinigu, bet ir valios bei bendradarbiavimo. Ir dèl to man labai malonu susipažinti su Tamsta ir pasišnekèti apie tą labai svarbu dalyką, - rašo K. Aglinskui kaunietis R. (1904) (4). Ši laišką vaistininkas persiunčia apmąstyti savo draugui, o $1905 \mathrm{~m}$. deda didžiules pastangas, kad Kaune eitų lietuviškas laikraštis, ir prašo daktaro J. Basanavičiaus būti jo organizatoriumi (1905 03 30).

1905 m. iš Garliavos vyksta i Tilžę pasitikti iš Bulgarijos sugrižtančio didžiausio savo gyvenimo draugo, nematyto 25 metus, lankyto tik laiškais, mintimis - prieš tai praneša atvirlaiškiu: kokiu nors būdu peršokęs siena, skubesiu su Lietuvos pasveikinimais. Pasitinka, abu kartu sugrižta i Garliavą - išsiilgtos kalbos, atokvejpio, bičiulystès. J. Basanavičius ir neketina grižžs apsistoti kur kitur - Garliava, Kazio namai, po užsienio jam atrodo pati mieliausia ir šilčiausia priebėga.

1907 m. K. Aglinskas kviečia J. Basanavičių aplankyti Garliavą, nes čia pradejjęs dirbti geras diakonas - lietuvis kunigas Zalanckas, ir pabrežiia - Tavo giminaitis. $19081208 \mathrm{~d}$. laiške dalijasi savo jauduliu, kad Vilniaus bažnyčiose įvedus lietuvių kalbą, kilo tokia stipri lenkų reakcija. İsteigus vartotojų bendrovę „Vilija“, rūpinasi jos veiklos sklandumu, metinèmis ataskaitomis.

Dažnas svečias, be J. Basanavičiaus, jo namuose būdavo garsusis pedagogas Tomas Žilinskas, Petras Kriaučiūnas „su savo moteria“ - visi taip pat kalbėdavo svarbiomis tautos gyvenimo temomis. Pats nuolat lankydavosi Zagrados dvare pas Kazimierą ir Ievą Gustaičius, važiuodavo ị Linksmakalnị - tuometinị Lustbergio palivarką, plačiai bendravo su tautiškai susipratusiais ir lietuvybę propaguojančiais kunigais, apskritai - daugeliu šviesių Suvalkijos regiono žmonių. Garliava, aplinkinių kaimelių vietovés, lietuviški patriotų dvareliai ir paties namai, virtę tikru lietuviškumo židiniu, K. Aglinskui buvo tapę jo gyvenimo alfa ir omega. Grįžęs iš Paryžiaus, aplankęs gražiąą Vieną, draugui daktarui nuoširdžiai prisipažista: vienok mieliausia buvo grižt Lietuvon! (1904).

Visuomeninio gyvenimo atgarsiai plačiai aidi K. Aglinsko laiškuose J. Basanavičiui - jam tai kur kas svarbiau nei siauro asmeninio gyvenimo problemos. Viena opiausių problemų, jaudinusių K. Aglinską, - didžiulè lietuvių emigracija. Jis labai išgyveno, kad daugèja i Ameriką išvykstančių lietuvių, kad beveik kasdien matyt per Garliava varomi atgal suimti emigrantai nuo prusiško rubežiaus (1892). Jị kankina mintis, kad nesant tautos žmonių, nebus kam išsaugot lietuvybę, dèl kurios tiek kovojama. 1904 m. su nerimu J. Basanavičiui rašo: Aš draugiškai Tau turiu pasakyt, kad daug metu lietuviai emigruoja i Amerika ir Afriką. Daugiau pusès žmoniu jau nèr. Gaspadoriai neturi darbininkų, nes šie palieka ponus už menkinima ir bèga į ta amerikoniška anglišką katorgą; paskutiniai treji metai - mažai vaisingi, Japonija su savo nelaimingu karu ypač pasunkino laika, taip kad nabagai lietuviai laukia

(4) Šio asmens nepavyko identifikuoti. 
laivu Hamburge ir Brèmene po dvi savaites - tiek ju emigruoja ir nèr turbūt būdo sulaikyt. Japonu karas atšaldo žmones nuo visokiu užsiemimu, ne vienas laukia jo pabaigos, kad pradètu kokị nors darba (1904 12 29). Visgi laiško pabaigoje turi ir kuo pasidžiaugti: Garliavoj isitaisé jomarkai ir nuo pavasario stojo paštas.

\section{Vaistininko rūpesčiai}

Turẻdamas problemų su sveikata $1891 \mathrm{~m}$. Kazys Aglinskas buvo išvykęs gydytis ị Vieną, kurioje praleido apie pora mėnesių. Grįždamas dar kurị laiką apsistojo Zakopanejje pasikonsultuoti su medikais, pailsèti kurorte, atgauti prarastas fizines ir dvasines jẻgas. Šių kelionių metu labai daug skaitė Vakarų Europos literatūros, domėjosi senovés graikų ir romėnų kultūriniu paveldu, lankèsi Austrijos ir Lenkijos muziejuose, parodose. Lenkijoje pabuvojo prie savo mylimo rašytojo Jozefo Ignacy Kraszewskio kapo. Nuolat mąste, kiek daug per civilizacijos istoriją pasiekė žmonijos išmintis, jau seniausiais laikais sukūrusi hieroglifus, akmeninius ir medinius sarkofagus, mumijas, iškilius literatūros šedevrus. Issigijo nemažai medicinos krypties knygų, skaitė naujus straipsnius medicinos tema, domëjosi neurastenijos gydymu - apie visa tai plačiai referavo laiškuose J. Basanavičiui. Apmąstẻ savo likimą kaip gana skaudų: prisiminè tragišką praeities įvykį, kai gilios žiemos metu arkliu kinkytomis rogėmis vykstant $\mathfrak{i}$ Aleksotą, šis pasibaidęs, rogés apvirtusios, ir taip arklys jị tempęs po jomis gana ilgą atkarpą; tada gavęs paralisis spinatis, ir daug kas tikèjęsis, kad mirs, bet jis išgyvenęs. Tačiau blogu oru vis tebevargina pasikartojantys dideli dešinès rankos ir kojų skausmai.

Abu bičiuliai, būdami medicinos krypties specialistai, turẻjo daug bendros kalbos apie šios srities reikalus. $1908 \mathrm{~m}$. K. Aglinskas darè didžiulę savo vaistinès rekonstrukciją, tikẻdamasis, kad dabar bus galima liuosiau kvépuoti. Apie tai jis rašo atvirlaiškyje J. Basanavičiui, kartu paminėdamas kokius vaistus ir kam skyrè, išsamiai aprašydamas kiekvienos ligos pobūdị, lotyniškus pavadinimus. Kai kuriuose laiškuose prašo J. Basanavičiaus iš užsienio parvežti tam tikrų vaistų, kurių esą negalima gauti čia ir kurių būtina turèti vaistinėje. 1909 m. lapkričio 2 d. rašytame atvirlaiškyje J. Basanavičiui K. Aglinskas skundžiasi, jog jam vienam dirbti Garliavoje sunku, ir prašo, jei pasitaikytų galimybe kur sutikti gerą vaistininką ar daktarą, turèti tai omenyje. Pats nuolat ieškojo pagalbininkès, galinčios darbuotis vaistinèje, tik ją sunku buvo rasti, mat kandidačių atvykdavo daug, bet jos nemokèdavusios lietuvių kalbos. Lietuvių kalba K. Aglinskui buvo vienas svarbiausių kriterijų priimant žmogų í ší darbą. Kartą pavyko tokią rasti, bet po kurio laiko ji išvyko steigti aptieka $i$ kita miesteli. 1907 m., ketindamas kažkur išvažiuoti, teiravosi J. Basanavičiaus, gal jam galètų pagelbèti aušrininko Davainio Silvestravičiaus dukra Liucè, kurią pakviestų padirbėti už ji kokiam mėnesiui ar ilgèliau, nes nenorịs patikèti savo aptiekèlès kokiam žydui ar gudui, tačiau šis atrašè, kad ji negalinti. Be to, vyro jis ir šiaip nenorịs priimti, nes vaistinėje nuo seno - personalas moteriškas. Abu svarstė ir nuolat Garliavoje dirbančio daktaro būtinumo klausimą, tuo rūpinosi.

1909 m. K. Aglinskui buvo neramūs, kupini nelauktų nutikimų. Gruodžio mėnesį miestelyje vykstant mugei, jis tampa nusikaltimo liudininku, kai plešikai stipriai sužeidžia žemsargi, o žandara lengvai; du plěšiku per ugni išbègo, vieni iš juju gavo kulkas. Po septynių valandų plèšikai pagauti Mauručiuose ir pasodinti i Kauno kalejimą. Incidento metu jis patiria nervinį sukrètimą, iš kurio išsivadavęs yra priverstas dalyvauti tardymuose, duoti parodymus, važinèti po teismus, o tai dar labiau sutrikdo jo dvasią. Rašo J. Basanavičiui, prašydamas ištardyti jo širdį, kad neatsitiktų kaip su vienu bendru draugu Butk. (pavardè nežinoma - aut. past.) (1909 03 21). 
K. Aglinskas aktyviai rūpinosi vietinių gyventojų, ir ne tik jų, bet ir visų lietuvių, reikalais ir gerove. Gavęs laišką, kad J. Basanavičiui kažkokiems tikslams reikalingi pinigai, užstato savo daiktus ir siunčia pinigų kvitą jo broliui Vincui į Ožkabalius. Su jauduliu J. Basanavičiui pareiškia, kad Aleksote gyvena Kudirka, bada kenčia. Garliavon nenor pareiti (1885 05 17). Iš laiško galima suprasti, kad su juo buvo susisiekęs, siūlè pagalbą. Viename atvirlaiškyje rašo J. Basanavičiui, kad Odesoje mokosi jaunuolis iš Garliavos, studentas Paršaitis, siūlo ir jam ten nuvykti pasigydyti sugverusị skilvị (1905). Su jauduliu praneša draugui, kad vietiniai valstiečiai moka kasmet Varšuvos ligonbučio „Tvorki“ išlaikymui: Fredos (Garliavos) valsčius - 284 rublius, Aleksoto - nuo 240 iki 280 rublių. Ir priduria: Surinksiu platesnes žinias tu dalyku (1909 04 17). Ruošiasi važiuoti ị Mauručius viską išsiaiškinti apie Skučą, ị Lietuvą grịžusị iš užsienio, jo medžiaginị stovį, nes atrodo, kad šis jokio kapitalo neturịs (5) (1912 09 24).

Trumpai referuoja, kad miręs ir Jonučių kapinèse palaidotas jiems gerai pažįstamas Feliksas Tomaševskis, kad viršaičiu liko patvirtintas Grybauskas (1907), kad staiga pasimirė Garliavos Šv. Trejybės bažnyčios diakonas Budzeika, todèl jis keturias dienas negalëjęs niekur išjudèti (1908).

1910 m. K. Aglinskas laišku teiraujasi J. Basanavičiaus, ar šis nenorįs, kaip anksčiau ketinęs, pirkti netoli Garliavos esančio Kalinavos dvaro, kurị šiuo metu parduoda savininkas. Kodèl J. Basanavičius dvaro neįsigijęs, nežinia.

Vienas svarbiausių to laikotarpio klausimų K. Aglinskui - lietuvių ir lenkų santykiai, pastebimas vis stiprejjantis lenkų siekis dominuoti krašte. $1911 \mathrm{~m}$. K. Aglinskas laiške dalijasi savo ịspūdžiais apie Viltyje skaitytą straipsnị, skirtą Garliavoje aktyviai besidarbuojantiems „šundaktariams“. Pabrěžia - juos palaiké lenkiška intekmé. Šie veikę medikai apsimetèliai bandyti sudrausminti; vis delto viskas liko po senovei, tik daktare turejo pasitraukt i kita namą kitoj gatvés pusej (1911 01 27). Kitame laiške rašo: Kaziui Gustaičiui iš Kairiūkščiu (6), kuris užmokèjęs už Kairiūkščius ir Lustbergi (7) prieš 3 metus 105000 rublių, šiandien lenkų epidemija moka jam jau už tuos du palivarkus 160 000. Žydelei Frankelei tesejjo kelis dvarus, kuriuos taipogi ponai lenkai nupirko. Mat lenkai kolonizuoja Lietuvą. Liūdna...

Daukšiagirè, Ašt[uonèlè] (8), Naujadvaris, Pag[irnuovonis], Pag[irmanka], Pušgrodas - Pakuonio apygardos yra naujai pirktos lenku. Beje, Malinavas...

Girdejau, ponia Biribienè gana brangiai užmokejjus už Kalinava - 32 000; vienok, kaip sako Baltrušaitis, jau lenkai duoda 36000.

Iš Varšuvos kontoros atėjo užklausimas, ar neparduodu savo aptiekos? Yra, sako, du kandidatai su gerais pinigais. Bet aš atsakau, kad varšuvietis jokiu būdu Garliavoje turèti aptiekos negali, nes be lietuviškos kalbos - ne vieno žingsnio padaryti negalès.

\section{Karo audrose}

1914 m. Lietuvai buvo dramatiški. Pačioje spalio pradžioje K. Aglinskas rašo daktarui viltingai klausdamas, ar šis nesiruošia kur toliau keliauti - jei neturètų ypatingo draugo, tai galètų imti jị kartu, tik turịs pranešti iš anksto. Akivaizdu, kad pasiryžęs kilti ị ilgesnę kelionę - pamatyti Europą, lankytis jos miestų muziejuose, parodose, domėtis moderniais kultūros pasiekimais. Tačiau netrukus netikètai prasideda Pirmasis pasaulinis karas. K. Aglinskas rašo J. Basanavičiui, kad nebegauna laikraščių iš Vilniaus ir Varšuvos, kad tankiai tenka

(5) Kuris Skučų giminès, gyvenusios Mauručiuose, atstovas turimas omenyje, nepavyko nustatyti.

(6) Kaimas Rokų rajone, $8 \mathrm{~km}$ nuo Garliavos Linksmakalnio pusėn.

(7) Linksmakalnio dvaras, $9 \mathrm{~km}$ nuo Garliavos link Prienų.

(8) Vietovių pavadinimai neįskaitomi. 
girdèti griausmas armotu, bet kol kas vietiniai žmonès elgiasi ramiai, apsipranta su tuom, kad prie šalies sienos rytų puseje dažnai aidi šaudymai, kad jų pažistamas Škéma parbėgo pas tèvą išsigandęs vokiškų bombų, kurias pradejo mètyt ant Varšuvos. Samprotaudamas apie karo veiksmų eigą pažymi, kad už Varšuvos ypatingai gerai Vilius (9) gavo, ir jeigu Krokuvoj taip nosị nudegs, tai ir karas sutrumpès (1914 10 20).

Kaip klostėsi K. Aglinsko ir J. Basanavičiaus bendradarbiavimas Voroneže, nežinia, nes tokių laiškų nèra išlikę. Praūžus Pirmojo pasaulinio karo audroms, didžiausias K. Aglinsko siekis - sugrịžti į tèvynę ir toliau darbuotis jos labui. 1918 m. liepos 29 d. džiaugsmingai rašo J. Basanavičiui: Br. J., laimingai grižau iš Voronežo Lietuvon. Ryt gausiu reikalingus popierius ir važiuosiu Garliavon. Tuomi tarpu siunčiu Tau širdingus pasveikinimus, laukdamas ypatingo pasimatymo. Tikiu, kad parašysi. Tavo Kazys. Kaunas.

Dar kitame laiške daktarui praneša, kad Voroneže parašè tekstą apie gamtą ir jos ìvairumą, kurị norètų publikuoti, bet prieš tai tikisi išgirsti J. Basanavičiaus „recenziją“. Voronežą prisimena nemaloniai, kaip îvairių nesèkmių vietą. Čia ji esą aplupo bolševikai - atèmé 320 rubliu aukso, 506 rubliu sidabro ir Brauningo sistemos revolverį. Beskaičiuojant pinigus dar dingo 24 rubliai; tada jis surašè nuostolius fiksuojantị protokolą, kurị pasirašè liudininkai. Ar atgavo prarastą turtą, žinių nèra. Laiške dar užsimenama, kad progai pasitaikius, reikètų pasirūpinti Grybauskų, bendrų pažistamų, grižusių Lietuvon, materialine būkle.

Viename iš paskutinių laiškų pranešama, kad kartu su kitais rūpinasi Vileišio namo ir fabriko pirkimu. Daug pajų neketinąs imti, kaip ir Kazys Gustaitis, bet agitaciją dèl to varo, išsiuntęs gimstančios Draugovés proklamacija kanauninkui Zalauckiui, tik kol kas atsako negavęs. Taigi tautos visuomeniniai reikalai ji lydèjo iki pačios gyvenimo pabaigos.

LLTI archyve išlikęs ir paskutinis K. Aglinsko laiškas J. Basanavičiui, rašytas $1924 \mathrm{~m}$. pavasarị - jau sunkiai susirgus, drebančia ranka: Rašau laiškelị patalynejj, 4 mènesiai guliu, kojos sudžiūvo kaip botagai, rankos kaip žagarai. Liga mano tokia: kaip paprastai, i senatve kimba obstrukcija, prie josios prikibo šaltis ir karštis, ypač jeigu pavalgai mésos. <>

Dabar klausiu apie Tavo sveikata? Girdejau, kad sirguliuoji - laikykis, brangus Jonai, Tavo vardas skamba kiekvienoj Lietuvos vietoj. Seniai apie Tavo pamerktas [neįskaitomas žodis] rožes... Lietuva ap[vainikavo] Tavo troškimus...

Jeigu sveikata pradèjo šlubuoti, ar nevertètu vasara pasinaudoti energišku oru Zakopanejje, daug turinčiu ozono. Tai yra kalnuota šalis, 200 metrų aukščiau už Krokuva - siena Galicijos ir Vengrijos - rezidencijos Adomo Mickaus (10) ir Juozo Kraševskio (11). <>

Geisdamas tau viso labo, ypač sveikatos - pasilieku

Tavo Kazys

Garliava, 19240502.

K. Aglinskas mirè rugpjūčio mėnesį. Ar sulaukè iki to laiko kokio J. Basanavičiaus laiško, nežinia. Tačiau J. Basanavičius aplankè savo sergantị draugą rugpjūčio $23 \mathrm{~d}$. - dieną prieš jo mirtị. Taip baigèsi didžioji garsių Lietuvos vyrų draugystè. Draugystė, kurios nenutraukè jokios politinès aplinkybès, ilgi išsiskyrimai, asmeninès negandos. Šią draugystę nutraukė tik mirtis. Ir paliko legenda.

(9) Vokietijos imperatorius Vilhelmas.

(10) Adomas Mickevičius.

(11) Jozefas Ignacy Kraszewskis. 


\section{IŠVADOS}

K. Aglinskas - vienas aktyviausių Maskvos lietuvių studentų būrelių XIX a. antrojoje pusèje steigèjų ir veiklos organizatorių, tautinès savimonės žadintojų. Maskvoje studijų metu susipažinęs su J. Basanavičiumi, tampa jo visuomeninès ir tautinès veiklos bendražygiu ir rèmëju. Apsigyvenęs Garliavoje, provizorius K. Aglinskas surengia savo vaistinėje nelegalios spaudos platinimo centrą, vieną svarbiausių Suvalkijoje, stambų lietuviškų knygų persiuntimo (iš kairiosios Nemuno pusès) punktą. Jis visokeriopai remia knygnešius ir jų veiklą.

Savo veikla daug prisideda prie Lietuvos mokslo draugijos kūrimo 1907 m.: padeda rengti draugijos įstatus, programą, svarsto veikimo kryptis. Jis remia draugiją materialiai ir knygomis, tampa tikruoju jos nariu labdariu.

Vienas reikšmingiausių K. Aglinsko gyvenimo momentų - glaudi draugystė su daktaru J. Basanavičiumi, kurią plačiai atskleidžia išlikę 92 jo laiškai. Laiškuose atsiveria nuoširdus siekis rūpintis lietuvybès ir visuomeniniais tautos gyvenimo reikalais, paties J. Basanavičiaus asmenybe. Dèl šios glaudžios draugystès J. Basanavičius itin dažnai buvoja pas K. Aglinską Garliavoje - kur kas dažniau nei savo tėviškejje Ožkabaliuose: čia jis ilsisi ir rašo savo straipsnius, vaikšto po girią, gydo žmones, renka istorinę, archeologinę, folklorinę ir kalbinę medžiagą; kasinėja kapines, užrašinėja dainas, pasakas, vietinių gyventojų prisiminimus apie grafą Godlevskị ir Napoleono kariuomenès žygị per Garliavos apylinkes. Tarp abiejų bičiuliu jaunystèje užsimezgusi draugystè tęsėsi iki jų gyvenimo pabaigos.

K. Aglinsko laiškai J. Basanavičiui liudija jị buvus žmogiškai jautrią, visuomeniškai ir socialiai orientuotą asmenybę. Visa jo gyvenimo veikla - tiek farmaciné, tiek slaptos spaudos platinimas, tiek visuomeninių organizacijų bei atgimimo judejimo rèmimas - liudija sąmoningą asmenybès apsisprendimą dirbti tautos labui nepasiduodant jokiems sunkumams ir bet kokiomis aplinkybèmis, aukojant tam viską.

Gauta 20130310 Priimta 20130517

\section{Literatūra ir šaltiniai}

[1] BASANAVIČIUS, J. Mano gyvenimo kronika ir nervu ligos istorija. 1851-1922 m. Vilnius: Baltos lankos, 1997.

[2] BŪDVYDIS, Leonas. Karštai mylintis tèvynę. Ave vita. Kauno medicinos akademija, 1992, Nr. 5.

[3] GRINIUS, Kazys. Atsiminimai. 1932, t. 2.

[4] KIRLYS, Jonas. Garliavos krašto knygnešiai. Kauno rajono savivaldybès viešoji biblioteka.

[5] Knygnešys. T. I. (2-as leidimas). Redaktorius P. Ruseckas. Kaunas: Varpas, 1929.

[6] KRUŠINSKAITĖ, E. Aušrininkas. Tẻviškés žinios, 1991, rugsẻjo 26.

[7] Kazio Aglinsko korespondencija Jonui Basanavičiui. LLTI biblioteka, F2-681, šifras J. B. 681.

[8] OVERLINGAS, Virgilijus. Kazys Aglinskas - tautinio atgimimo veikèjas. Tèviškés žinios, 1996, gruodžio 7-13.

[9] STRUKČINSKAS, Mindaugas. „Gyvenę Lietuvai“. Tèviškès žinios, 1994, rugsèjo 24. 
INGA STEPUKONIENÉ

\title{
Friendship of pharmaceutical chemist in Garliava Kazys Aglinskas and Jonas Basanavičius
}

\author{
Summary
}

Kazys Aglinskas was one of the most active founders of Lithuanian students' groups in Moscow in the second half of the 198th century, the organizer of their activities and an active promoter of national consciousness. During his studies in Moscow, he got acquainted with Jonas Basanavičius and became the supporter of his national activities. When he moved to Garliava, pharmaceutical chemist Aglinskas established the centre of disseminating illegal press in his pharmacy, which became one of the most important centers in Suvalkija, sending Lithuanian books from the left side of Nemunas on a massive scale. He supported book spreaders (knygnešiai) and their activities by all means.

With his activities, he contributed significantly to the establishment of the Lithuanian Science Association in 1907, helped in preparing its statute, programme and discussed the areas of activities. Aglinskas supported the Association financially and by donating books and became its real member and supporter.

One of the most significant moments in Kazys Aglinskas' life is his close friendship with doctor Jonas Basanavičius, which is revealed by 92 letters written to Basanavičius. The letters reveal Aglinskas' sincere concern about Lithuania and public issues of the nation, as well as Basanavičius himself. Because of the close friendship, Basanavičius visited Aglinskas in Garliava very often, even more often than his native place in Ožkabaliai. In Garliava he had some rest, wrote articles, went for a walk in the forest, cured people, and collected historical, archaeological, folklore and linguistic material. He also made excavations in the cemetery, wrote down songs, tales and the memories of people about count Godlevski and Napoleon's march in the surroundings of Garliava. The friendship between these two people lasted until the end of their lives.

Aglinskis' letters signify that he was a sensitive and socially-publicly oriented personality. All his activities (pharmaceutical, disseminating secret press or supporting public organizations and the Rebirth Movement) emphasize his conscious choice of working for the sake of the nation, overcoming various difficulties and circumstances, as well as sacrificing everything for these issues.

Key words: spreaders of Aušra Newspaper, secret Lithuanian press, public activities 